\title{
Adoption of Electronic Fiscal Devices (EFDs) for Value-Added Tax (VAT) Collection in Kenya and Tanzania: A Systematic Review
}

\section{Emmanuel Eilu}

Lecturer, Uganda Christian University, Mukono, Uganda

\begin{abstract}
Domestic revenue collection through taxation is still below its potential in many SubSaharan African countries. In an attempt to boost their tax revenues, many national governments have deployed electronic fiscal devices (EFDs) to improve value-added $\operatorname{tax}$ (VAT) collection. However, there is evidence indicating that the deployment of EFDs in some African countries has encountered substantial challenges. Using the systematic review method, the research described in this article investigated challenges encountered in adoption of EFDs in Kenya and Tanzania. The review concludes by modelling recommendations, extracted from seven existing studies, in terms of the technology-organisation-environment (TOE) framework (Tornatzky \& Fleisher, 1990). This model is an effort to provide a potential guide for successful EFD adoption in East Africa.
\end{abstract}

\section{Keywords}

electronic fiscal devices (EFDs), electronic tax registers (ETRs), value-added tax (VAT), tax collection, information and communication technology (ICT), technology-organisationenvironment (TOE) framework, Kenya, Tanzania

DOI: https://doi.org/10.23962/10539/26169

\section{Recommended citation}

Eilu, E. (2018). Adoption of electronic fiscal devices (EFDs) for value-added tax (VAT) collection in Kenya and Tanzania: A systematic review. The African Journal of Information and Communication (AJIC), 22, 111-134. https://doi.org/10.23962/10539/26169

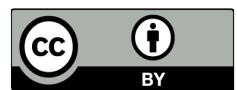

This article is licensed under a Creative Commons Attribution 4.0 International (CC BY 4.0) licence: http://creativecommons.org/licenses/by/4.0 


\section{Introduction}

\section{Tax collection in Sub-Saharan Africa}

Tax revenue is a vital pillar in support of economic growth in developing countries. Taxation is the main source of central government revenue for state-building, elimination of long-term dependence on foreign assistance, increasing the fiscal effects of trade liberalisation, and providing much-needed public goods and services (Fjeldstad, 2011; Mascagni et al., 2014; OECD, 2011). Tax-to-GDP ratios in many developing countries are much lower than in developed-world countries, i.e., the members of the Organisation for Economic Co-operation and Development (OECD) (Mascagni et al., 2014). The African Development Bank (2011) found that between 2006 and 2008, the countries of the East African region-Kenya, Tanzania, Uganda, Rwanda and Burundi-had tax-to-GDP ratios ranging from $12.3 \%$ to $22.1 \%$. Meanwhile, OECD countries and South Africa had tax-to-GDP ratios averaging $35.6 \%$ (AfDB, 2011).

In Sub-Saharan African countries, total tax revenue collected typically only funds $30 \%$ to $40 \%$ of the national budget (Ebeke \& Ehrhart, 2010), forcing most of these countries to seek budget supplements from donors. According to the World Bank (2010), Sub-Saharan Africa received USD40.1 billion in aid in 2008 alone. "Tax effort" indices-i.e., tax revenue collected as a percentage of total estimated tax revenue potential-are also lower in Sub-Saharan Africa than in OECD countries (10-20\% in Sub-Saharan Africa compared to $30-40 \%$ in the OECD) (Mascagni et al., 2014).

In an attempt to increase tax revenues, a number of Sub-Saharan African countries have introduced new taxes, including value-added taxes (VATs). Generally referred to as a tax on consumption, a VAT is an indirect tax levied on the production, distribution and consumption stages of products and services. In 2013, as shown in Table 1, VAT was estimated to be contributing $31.7 \%$ of total revenue in Uganda, $31 \%$ in Rwanda, 27.6\% in Tanzania, 26.4\% in South Africa, and 23\% in Kenya (URA, 2013).

\section{Figure 1: VAT contribution to total revenue}

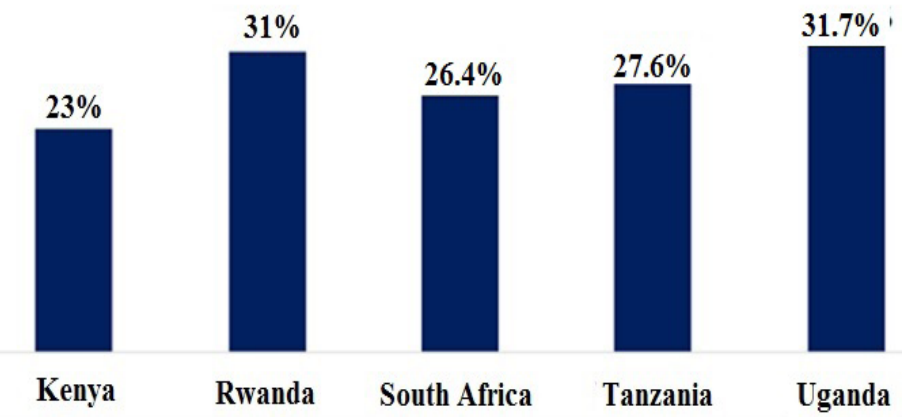

Source: URA (2013) 
However, authorities in these same countries are grappling with the challenge of significant levels of non-compliance among VAT-payers and potential VAT-payers. For example, in Kenya between 2000 and 2003, 30\% of the total tax revenue came from VAT, but this percentage had declined to $23 \%$ by 2013, with one of the reasons for the decline being a high rate of VAT non-compliance (Mativo et al., 2015; URA, 2013).

\section{Tax collection via electronic fiscal devices (EFDs)}

While there are a number of ways in which countries can reduce VAT non-compliance, it is difficult to conceive of an efficient and effective tax administration that can perform its tasks without making substantial use of information and communication technology (ICT) (Eilu, 2018). Accordingly, several tax authorities in Sub-Saharan Africa have deployed electronic fiscal devices (EFDs) (Casey \& Castro, 2015). EFDs are computerised devices used by tax bodies to monitor the business transactions of each registered business. One form of EFD is an electronic cash register (ECR), which is a point-of-sale terminal that records information from barcode scanners, weighing scales, and credit and debit card machines. Another form of EFD is an electronic tax register (ETR), which is like an electronic cash register but with one distinct difference: the ETR calculates the tax value for every transaction made and stores this information in a permanent memory that can only be accessed by the tax body.

EFDs were first used in the 1980s, in Japan and several countries in Europe. In recent years, there has been accelerated deployment of EFDs in Sub-Saharan Africa (Casey \& Castro, 2015). In 2005, Kenya became the first East African country to implement EFDs, followed by Tanzania in 2010 and Rwanda in 2014 (Casey \& Castro, 2015). The deployments of EFDs in Kenya and Tanzania have encountered significant challenges. Casey and Castro (2015) attribute the difficulties to factors such as lack of effective compliance-monitoring, lack of effective follow-up strategy, and absence of enforcement measures.

In Kenya, EFDs (i.e., ETRs) were mandated by Gazette Notice No. 47 of 22 October 2004. During the initial implementation stages, beginning in 2005, there was wide scepticism in Kenya regarding the value of EFDs, and this scepticism has persisted (Mativo et al., 2015). Casey and Castro (2015) observe that in Kenya, since the introduction of EFDs in 2005, there has been no sustained tax revenue increase, suggesting the introduction of EFDs has not brought any substantial gains.

In Tanzania, EFDs (i.e., ETRs) were introduced in 2010, with the stated objectives of improving VAT collection through eliminating non-issuance of receipts, eliminating under-invoicing of sales transactions, improving filing process of VAT returns, and assisting traders in keeping proper business records (Kapera, 2017). There is evidence that the initial EFD deployment was undermined in Tanzania by compliance 
challenges and lack of effective follow-up and enforcement (Casey \& Castro, 2015; Naibei et al., 2012).

In Rwanda, deployment of EFDs (i.e., ETRs) started in March 2014. By September of that year, 3,943 VAT-collecting firms had active EFDs, representing $77.8 \%$ of all VAT-registered firms. However, a study found out that the introduction of EFDs had led to only a $5.4 \%$ increase in VAT revenue, much lower than the expectation by the Rwanda Revenue Authority (Steenbergen, 2017). In reference to the EFD deployment in Rwanda, Steenbergen (2017) states that "the overall effect of EFDs on tax yields has been disappointing" (2017, p. 21).

\section{A systematic revierw: EFD challenges in Kenya and Tanzania}

For my study, I used the systematic review method, which requires a step-by-step, comprehensive, and detailed literature search based on a clear research problem, clear research objectives and clear research questions. The goal of a systematic search of literature is to fuse and evaluate all relevant studies on a particular topic, based on the research questions. In this study, the systematic review focused on reviewing the findings of studies that have assessed EFD implementation in Kenya and Tanzaniathe first two countries in East Africa to adopt EFDs.

The systematic review generated data from seven existing studies looking at both the challenges, and recommendations for improvement, of EFD adoption in Kenya and Tanzania. After summarising and analysing that data, I subjected the data to an additional level of analysis, in order to generate a proposed model for successful EFD adoption in East Africa. In generating that model, I relied on the technologyorganisation-environment (TOE) framework developed by Tornatzky and Fleisher (1990).I used the TOE framework to provide a taxonomy for classifying the different requirements for adopting EFDs in East Africa.

\section{The technology-organisation-environment (TOE) framework}

Many theories have been developed for understanding the dynamics of technology adoption. The most-used theories are the technology acceptance model (TAM) (Davis, 1986; 1989; Davis et al., 1989), the theory of planned behaviour (TPB) (Ajzen, 1985; 1991), the unified theory of acceptance and use of technology (UTAUT) (Venkatesh et al., 2003), the diffusion of innovation (DOI) model (Rogers, 1995), and the TOE framework (Tornatzky \& Fleischer, 1990). The DOI and TOE frameworks can be applied at both individual and firm levels, while the remainder of the above-listed theories are applicable only at the individual level (Oliveira \& Martins, 2011).

In their individual capacities, these theories cannot account for all of the dynamics of adoption of new technology in a country, because of each country's particular social, cultural, political and economic dynamics. DOI attempts to cover a number of critical requirements that aid technology adoption in a developing-country setting, 
but Hoti (2015) argues that the DOI model should be combined with other contexts or factors for a more holistic adoption picture. It is in line with this argument that Hoti (2015) recommends the TOE framework, which includes the environmental context that in many respects is not included in DOI. TOE defines the process by which a firm adopts and implements technological innovations, considering the influences of the technological, organisational, and environmental contexts (Tornatzky \& Fleischer, 1990). According to Oliveira and Martins (2011), the TOE framework provides a good understanding of IT adoption decisions in different contexts, and it provides a taxonomy for classifying adoption factors in their three respective contexts- a quality many other models do not have.

In the TOE model, the technology (T) context refers to characteristics of the technologies available for possible adoption by the organisation, and the current state of technology in the organisation. This current state of technology can be expressed in both material (e.g., equipment owned by the organisation) and immaterial (e.g., methods currently in use) terms. The organisation (O) context consists of the organisational structure; the presence of innovation-enabling processes such as informal communication and strategic behaviour of top management; and the amount of extra resources available for use internally within the organisation. The environment $(E)$ context combines factors such as market structure and characteristics; the external support available for adopting new technologies; and government regulations. As seen in Figure 2 below, the three TOE contexts are posited to interact with each other and to influence technological innovation and decision-making, which in turn impact adoption dynamics (Tornatzky \& Fleischer, 1990).

Figure 2: TOE framework (Tornatzky \& Fleischer, 1990)

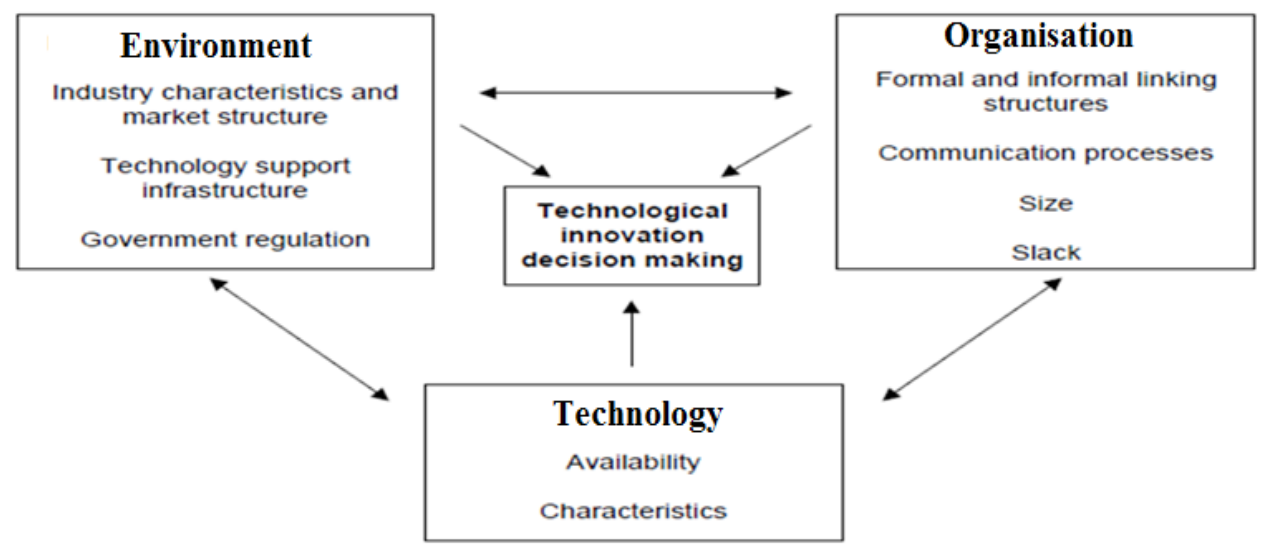

Source: Tornatzky and Fleischer (1990, p. 76) 
TOE theory has been used by a large number of technology adoption studies, e.g., investigations of adoption of electronic data interchange (EDI), adoption of open systems, and e-business adoption. Most of these studies applied the TOE framework in a developed-country setting. As far as I am aware, there has been little or no application of this model in Sub-Saharan African national settings.

\section{Research design}

As stated above, the research method followed was a systematic review. The systematic review method has its roots in criticism from scholars towards non-systematic, narrative-style literature reviews (DFID, 2013). Scholars have criticised narrativestyle literature reviews on the grounds that they are insufficiently rigorous (DFID, 2013). A systematic review involves a step-by-step plan based on a clear research problem and clear objectives and questions (Hagen-Zanker \& Mallett, 2013).

Kenya and Tanzania were chosen as focus countries for this study because they were the first East African nations to adopt EFDs, and because their adoption of EFDs was long enough, since 2005 and 2010 for Kenya and Tanzania respectively. There was a substantial body of literature on the progress of the implementations. In the systematic review, I followed the five-stage process proposed by Randolph (2009, p. 4), namely: (1) formulation of the research problem; (2) collection of data; (3) evaluation of the data; (3) analysis and interpretation of the data; (5) public presentation of the data.

\section{Research problem}

The research problem I identified was the need to try to develop a model, based on experiences to date in Kenya and Tanzania, for the future of EFD adoption and implementation in East Africa.

\section{Research objectives}

In line with this problem definition, the core research objectives were to:

- understand the challenges of EFD adoption that have been identified by existing research in Kenya and Tanzania;

- understand the recommendations that have been made in this literature for successful adoption; and

- develop a model for potential guidance to East African countries that have adopted, or are planning to adopt, EFDs.

\section{Research questions}

Accordingly, the three overarching research questions were as follows:

1. Based on the findings presented in the existing literature, what have been the challenges of EFD adoption in Kenya and Tanzania?

2. Based on the findings presented in the existing literature, what recommendations have emerged for more successful EFD adoption in Kenya and Tanzania? 
3. Based on the findings presented in the existing literature, what kind of model emerges for successful adoption of EFDs in Kenya and Tanzania and, in turn, for other East African countries?

\section{Data collection}

An extensive literature search was conducted to identify studies that have looked at the challenges encountered, and recommendations for improvement, in adoption of EFDs in Kenya and Tanzania. The literature search's selection criteria were directly guided by the first two research questions listed above. The core keywords that were identified and searched for were: Kenya; Tanzania; electronic fiscal devices (EFDs); electronic cash registers (ECRs); electronic tax registers (ETRs); EFD challenges; EFD recommendations.

\section{Data evaluation}

The literature reviewed covered journal articles, books, reports, Master's and $\mathrm{PhD}$ dissertations/theses, conference proceedings, and websites. Google Scholar was the main tool used for the searching. The selection of literature to be analysed was based on the keywords and how comprehensively each item addressed the first two research questions. Initially, 30 items were found to address some aspects of the keywords. A more refined search was then made across those 30 studies, and it was found that seven studies comprehensively covered the content suggested by the keywords. Therefore, these seven studies were used for data evaluation (see "data evaluation" sub-section below).

I used a simple data extraction table to generate an overview of the data drawn from the seven studies, categorising each study in terms of its: author(s), year of publication, country of study, town/city of study, EFD technology studied, and number of respondents in the study.

\section{Data analysis and interpretation}

The data analysis sought both heterogeneity and homogeneity across the studies' findings, in terms of both: challenges identified; and recommendations made. First, the challenges and recommendations presented in each study were represented in tabular form: one table for each study. Then the challenges data were summarised and analysed across the seven studies, followed by summary and analysis of the recommendations data across the seven studies.

Finally, I made use of the TOE framework (Tornatzky \& Fleisher, 1990) to generate a taxonomy for classifying the recommendations that emerged from the systematic review, ultimately producing a potential model for successful EFD adoption in East Africa countries. 


\section{Public presentation}

This article represents a key element of my implementation of the fifth systematicreview pillar in the process outlined by Randolph (2009): public presentation of data.

\section{Data analysis and interpretation part one: The seven studies}

As outlined above, the literature search and evaluation identified seven studies that clearly discuss challenges and recommendations in respect of EFD deployment in Kenya or Tanzania. In the group of seven studies, conducted between 2011 and 2017, three are from Kenya, four from Tanzania (see Table 1).

Table 1: The seven studies

\begin{tabular}{|l|c|c|c|c|c|}
\hline \multicolumn{1}{|c|}{ Author(s) } & Year & $\begin{array}{c}\text { Country } \\
\text { of study }\end{array}$ & $\begin{array}{c}\text { Town/ } \\
\text { city of } \\
\text { study }\end{array}$ & $\begin{array}{c}\text { EFD } \\
\text { technology } \\
\text { studied }\end{array}$ & $\begin{array}{c}\text { No. of } \\
\text { respondents }\end{array}$ \\
\hline $\begin{array}{l}\text { Omweri, Obongo, } \\
\text { Obara and } \\
\text { Onsongo }\end{array}$ & 2011 & Kenya & Kisii & ETRs & 98 \\
\hline $\begin{array}{l}\text { Mativo, Muturi } \\
\text { and Nyang'au }\end{array}$ & 2015 & Kenya & Nairobi & ETRs & 78 \\
\hline $\begin{array}{l}\text { Maisiba and } \\
\text { Atambo }\end{array}$ & 2016 & Kenya & $\begin{array}{c}\text { Uasin } \\
\text { Gishu }\end{array}$ & ETRs & 102 \\
\hline Bakar & 2014 & Tanzania & Tanga & ETRs & 36 \\
\hline Siraji & 2015 & Tanzania & Mwanza & ETRs & 205 \\
\hline Kira & 2016 & Tanzania & Dodoma & ETRs & 75 \\
\hline Kapera & Tanzania & Arusha & ETRs & 120 \\
\hline
\end{tabular}




\section{Study one: Omweri et al. (2011)}

Omweri, Obongo, Obara and Onsongo (2011) assess the effectiveness of ETRs in the processing of VAT returns in Kisii Town in Kenya. The study was conducted on 98 VAT-registered businesses in Kisii town, including: services providers, wholesalers, and large-scale retailers including supermarkets. A number of challenges are identified, and recommendations provided, as shown in Table 2.

Table 2: Challenges and recommendations identified by Omweri et al. (2011)

\begin{tabular}{|l|}
\hline Challenges \\
\hline ETRs are expensive \\
\hline ETRs do not suit their kinds of businesses \\
\hline ETRs give inaccurate records \\
\hline ETR machine cannot be used in all businesses \\
\hline Some businesses already have point-of-sale devices \\
\hline Recommendations \\
\hline ETR costs should be payable in instalments \\
\hline ETRs should be compatible with legacy computer systems in business \\
premises \\
\hline ETRs should be free \\
\hline Kenya Revenue Authority (KRA) should introduce cheaper ETRs \\
\hline KRA should introduce more robust ETRs that have fewer breakdowns \\
\hline KRA should train VAT-collecting businesses on use of EFDs \\
\hline KRA should introduce different EFD systems for different businesses \\
\hline KRA should reimburse ETR servicing expenses \\
\hline
\end{tabular}

\section{Study two: Mativo et al. (2015)}

Mativo, Muturi and Nyang'au (2015) investigate factors affecting utilisation of ETRs among small- and medium-sized enterprises (SMEs) in the central business district of the Kenyan capital, Nairobi. The study involved 78 VAT-collecting businesses. Table 3 summarises the challenges and recommendations identified by the study. 
Table 3: Challenges and recommendations identified by Mativo et al. (2015)

\begin{tabular}{|l|}
\hline Challenges \\
\hline inadequate training for VAT-collecting enterprises on use of EFDs \\
\hline constant changes in technology make the ETR machines obsolete \\
\hline ETR maintenance services not provided by suppliers \\
\hline high cost of purchasing the ETR \\
\hline a large number of enterprises perceive VAT as not important \\
\hline Recommendations \\
\hline more training for VAT-collecting enterprises on use of EFDs \\
\hline provide ETR machines to VAT-collecting enterprises at no cost \\
\hline sensitise SMEs on importance of VAT \\
\hline impose penalties for late filing of VAT returns \\
\hline
\end{tabular}

\section{Study three: Maisiba and Atambo (2016)}

The Maisiba and Atambo (2016) study looks at the effect of EFDs on the revenue collection efficiency of the Kenya Revenue Authority (KRA) in Uasin Gishu County. The study targeted a population of 102 respondents, who included employees of KRA and Uasin Gishu VAT-collecting businesses. Results are presented in Table 4.

Table 4: Challenges and recommendations identified by Maisiba and Atambo (2016)

\begin{tabular}{|l|}
\hline Challenges \\
\hline usability problems \\
\hline poor, congested network during peak hours \\
\hline lack of training of VAT-collecting businesses on use of EFDs \\
\hline lack of reliable power supply to power the EFDs \\
\hline Recommendations \\
\hline make VAT filing and payment easier for VAT-collecting businesses \\
\hline extend working hours for KRA so as to enable tax filings after business hours \\
\hline increase training of VAT-collecting businesses on use of EFDs \\
\hline support cost of stable electricity to power EFDs \\
\hline
\end{tabular}




\section{Study four: Bakar (2014)}

The study by Bakar (2014) assesses the extent to which EFDs leverage VAT collection volume. This study was conducted at the offices of the Tanzania Revenue Authority (TRA) in Tanga City, and 36 VAT-collecting businesses were studied. Although the study found that EFDs had a significant impact on VAT collections, the study also revealed significant challenges in the EFD implementation process which, if addressed, would have positive effects on VAT compliance and revenue volumes. Table 5 presents the challenges and recommendations identified by the study.

Table 5: Challenges and recommendations identified by Bakar (2014)

\begin{tabular}{|l|}
\hline Challenges \\
\hline regular EFD breakdowns/malfunctions \\
\hline battery problems \\
\hline resistance to EFD use from VAT-collecting businesses \\
\hline errors in the vendor issuance of receipts \\
\hline businesses' failure to report EFD faults \\
\hline $\begin{array}{l}\text { lack of knowledge of how to use EFDs, i.e., lack of training of VAT-collecting } \\
\text { businesses on use of EFDs }\end{array}$ \\
\hline customers not demanding receipts \\
\hline weak network signals for transmission of electronic reports to TRA \\
\hline difficulty in monitoring EFDs after working hours \\
\hline Recommendations \\
\hline greater government political and financial support for EFD use \\
\hline $\begin{array}{l}\text { sustained training and sensitisation of VAT-collecting businesses, and other } \\
\text { relevant stakeholders, on use of EFDs }\end{array}$ \\
\hline effective monitoring and evaluation of EFD system \\
\hline punitive measures against falsified refund claims \\
\hline forging of better relationship between TRA and VAT-collecting businesses \\
\hline closer TRA monitoring of EFD-using businesses \\
\hline
\end{tabular}




\section{Study five: Siraji (2015)}

The Siraji (2015) study focuses on the challenges faced by taxpayers in using EFDs in Tanzania's Mwanza City, Nyamagana District. A sample of 205 VAT-collecting businesses was selected through stratified random sampling and purposive sampling. The study findings are provided in Table 6.

Table 6: Challenges and recommendations identified by Siraji (2015)

\begin{tabular}{|l|}
\hline Challenges \\
\hline high cost of EFDs \\
\hline lack of training of VAT-collecting businesses on use of EFDs \\
\hline time-consuming EFD operations \\
\hline power outages \\
\hline lack of technical support \\
\hline Recommendations \\
\hline provide training to VAT-collecting businesses on use of EFDs \\
\hline subsidise cost of, or remove import tax on, EFDs \\
\hline deploy TRA liaison officers to build relationships with traders \\
\hline establish EFD maintenance centres \\
\hline
\end{tabular}

\section{Study six: Kira (2016)}

Kira's (2016) study looks at perceptions of EFD use among VAT-taxpayers in the Tanzanian capital, Dodoma, identifying a number of challenges. The study was conducted on a sample size of 75 VAT-collecting businesses. The challenges and recommendations identified are shown in Table 7.

Table 7: Challenges and recommendations identified by Kira (2016)

\begin{tabular}{|l|}
\hline Challenges \\
\hline usability of EFD machines \\
\hline high cost of EFD machines \\
\hline EFD network problems \\
\hline lack of training of VAT-collecting businesses on use of EFDs \\
\hline insufficient number of EFD suppliers \\
\hline
\end{tabular}




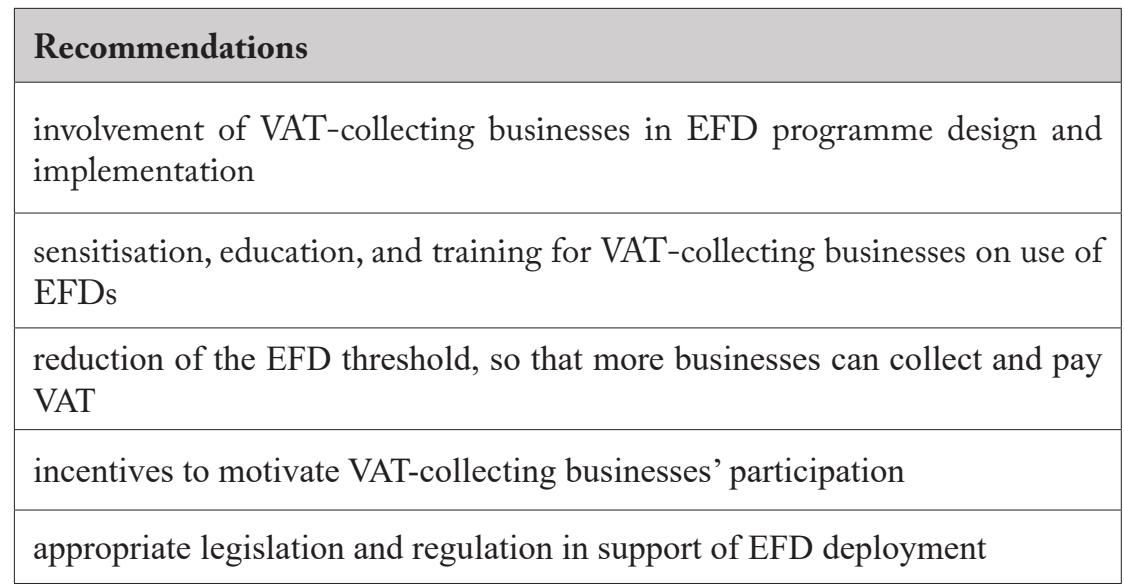

\section{Study seven: Kapera (2017)}

Kapera's (2017) study looks at the effectiveness of EFDs in tax collection in Arusha, Tanzania. The study sampled 100 VAT-registered traders and 20 TRA staff, for a total of 120 respondents. The identified challenges and recommendations are in Table 8 .

Table 8: Challenges and recommendations identified by Kapera (2017)

\begin{tabular}{|l|}
\hline Challenges \\
\hline the high cost of purchasing the devices \\
\hline lack of training of VAT-collecting traders on use of EFDs \\
\hline breakdowns in the EFD system \\
\hline lack of trader motivation to use EFDs \\
\hline lack of trader trust in EFD system \\
\hline Recommendations \\
\hline more fairness in TRA estimations of traders'VAT obligations \\
\hline provision of more training to VAT-collecting traders on use of EFDs \\
\hline stronger enforcement of VAT collection laws \\
\hline improvement of EFD technology \\
\hline
\end{tabular}




\section{Data analysis and interpretation part two: Across the seven studies}

\section{Challenges and recommendations for using EFDs in Kenya and Tanzania}

Table 9 lists key challenges encountered by the EFD programmes in Kenya and Tanzania, and the frequency with which each challenge is cited across the seven studies identified via the systematic review.

Table 9: Challenges: Frequency of citation across the seven studies

\begin{tabular}{|c|c|c|c|c|c|c|c|}
\hline Challenges & $\begin{array}{l}\text { Omweri } \\
\text { et al. } \\
(2011)\end{array}$ & $\begin{array}{l}\text { Mativo et } \\
\text { al. (2015) }\end{array}$ & $\begin{array}{c}\text { Maisiba } \\
\text { and } \\
\text { Atambo } \\
(2016)\end{array}$ & $\begin{array}{l}\text { Bakar } \\
(2014)\end{array}$ & $\begin{array}{l}\text { Siraji } \\
(2015)\end{array}$ & $\begin{array}{l}\text { Kira } \\
(2016)\end{array}$ & $\begin{array}{c}\text { Kapera } \\
(2017)\end{array}$ \\
\hline usability problems & & & $\mathbf{x}$ & & $\mathbf{x}$ & $\mathbf{x}$ & \\
\hline high cost of EFDs & $\mathbf{x}$ & $\mathbf{x}$ & & & $\mathbf{x}$ & $\mathbf{x}$ & $\mathbf{x}$ \\
\hline $\begin{array}{l}\text { poor network } \\
\text { connection }\end{array}$ & & & $\mathbf{x}$ & $\mathbf{x}$ & & $\mathbf{x}$ & \\
\hline $\begin{array}{l}\text { lack of training of } \\
\text { businesses (and other } \\
\text { stakeholders) on use } \\
\text { of EFDs }\end{array}$ & & $\mathbf{x}$ & $\mathbf{x}$ & $\mathbf{x}$ & $\mathbf{x}$ & $\mathbf{x}$ & $\mathbf{x}$ \\
\hline few EFD suppliers & & & & & & $\mathbf{x}$ & \\
\hline $\begin{array}{l}\text { malfunctions and } \\
\text { errors }\end{array}$ & $\mathbf{x}$ & & & $\mathbf{x}$ & & $\mathbf{x}$ & $\mathbf{x}$ \\
\hline $\begin{array}{l}\text { customers not } \\
\text { demanding receipts }\end{array}$ & & & & $\mathbf{x}$ & & & \\
\hline $\begin{array}{l}\text { difficulty in } \\
\text { monitoring EFDs and } \\
\text { businesses using them }\end{array}$ & & & & $\mathbf{x}$ & & & \\
\hline $\begin{array}{l}\text { obsolete EFD } \\
\text { machines }\end{array}$ & & $\mathbf{x}$ & & & & & \\
\hline power outages & & & $\mathbf{x}$ & & $\mathbf{x}$ & & \\
\hline $\begin{array}{l}\text { lack of technical } \\
\text { support }\end{array}$ & & $\mathbf{x}$ & & & $\mathbf{x}$ & & \\
\hline $\begin{array}{l}\text { failure by businesses } \\
\text { to report EFD faults }\end{array}$ & & & & $\mathbf{x}$ & & & \\
\hline $\begin{array}{l}\text { lack of motivation } \\
\text { to use EFDs among } \\
\text { businesses }\end{array}$ & & & & & & & $\mathbf{x}$ \\
\hline $\begin{array}{l}\text { lack of trust in EFDs } \\
\text { among businesses }\end{array}$ & & & & & & & $\mathbf{x}$ \\
\hline $\begin{array}{l}\text { inappropriate } \\
\text { technology }\end{array}$ & $\mathbf{x}$ & & & & & & \\
\hline
\end{tabular}


Figure 3 provides percentages for the frequency with which each of the above-listed challenges was cited across the seven studies.

\section{Figure 3: Challenges: Frequency of citation, in \% terms, across the seven studies}

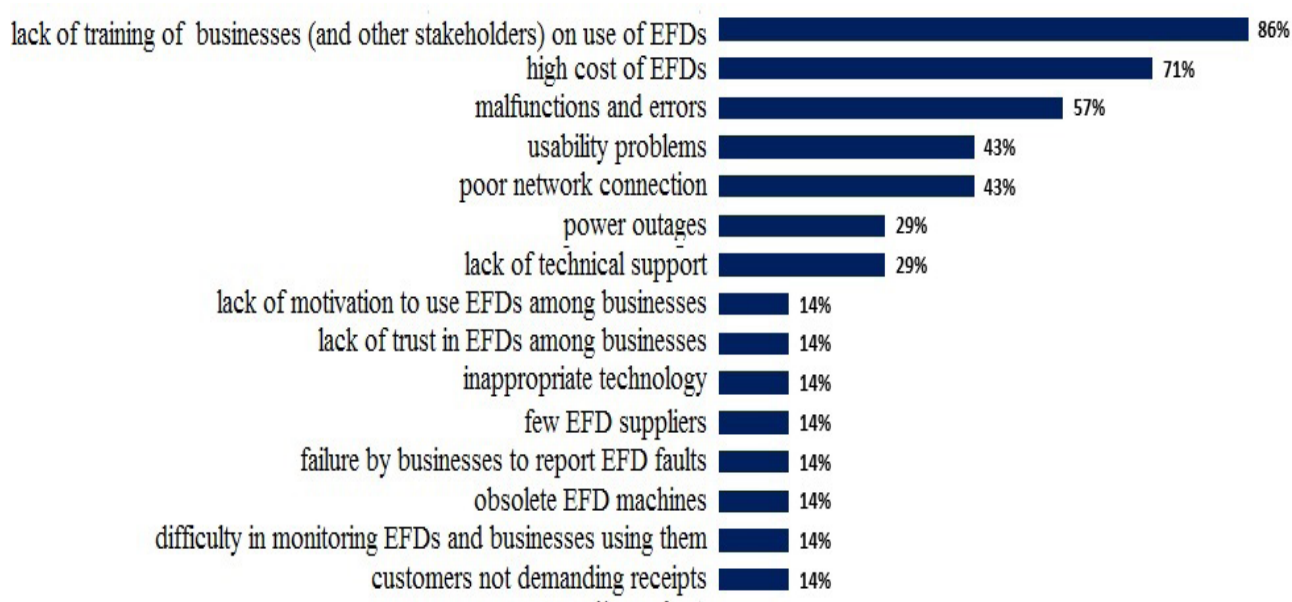

The results, as indicated in Figure 3, show that in the studies, the most-cited challenge affecting the use of EFDs in Kenya and Tanzania was lack of training of VAT-collecting businesses (and, to a lesser extent, other stakeholders) on the use of EFDs. This challenge was identified in six (86\%) of the studies. The second-most-cited challenge was the high cost of EFDs, as identified in five (71\%) of the studies. Malfunctions and errors were the third-most-cited category of challenge, identified in four (57\%) of the studies. Two challenges-poor network connection and usability problems - were each cited as a challenge in three (43\%) of the studies. Two challenges-lack of technical support, and power outages-were each identified in two (29\%) of the studies. Other key challenges, each identified in only one study, were: inappropriate technology; lack of trust in EFD system among VAT-collecting businesses; lack of motivation to use EFDs among VAT-collecting businesses; VAT-collecting businesses' failure to report EFD faults; EFD machine obsolescence; difficulty in monitoring EFDs and the businesses using them; lack of customer demand for receipts; and few EFD suppliers. 
Table 10 lists key recommendations for fostering EFD adoption, and the frequency with which each recommendation appears in the seven studies identified via the systematic review.

Table 10: Recommendations: Frequency of citation across the seven studies

\begin{tabular}{|c|c|c|c|c|c|c|c|}
\hline Recommendations & $\begin{array}{l}\text { Omweri } \\
\text { et al. } \\
(2011)\end{array}$ & $\begin{array}{l}\text { Mativo } \\
\text { et al. } \\
(2015)\end{array}$ & $\begin{array}{l}\text { Maisiba } \\
\text { and } \\
\text { Atambo } \\
(2016)\end{array}$ & $\begin{array}{l}\text { Bakar } \\
(2014)\end{array}$ & $\begin{array}{l}\text { Siraji } \\
(\mathbf{2 0 1 5 )}\end{array}$ & $\begin{array}{l}\text { Kira } \\
(2016)\end{array}$ & $\begin{array}{c}\text { Kapera } \\
(2017)\end{array}$ \\
\hline $\begin{array}{l}\text { government political } \\
\text { and financial support } \\
\text { for EFD programme }\end{array}$ & & & & $\mathbf{x}$ & & & \\
\hline $\begin{array}{l}\text { sustained sensitisation, } \\
\text { education and training } \\
\text { of businesses (and other } \\
\text { stakeholders) }\end{array}$ & $\mathbf{x}$ & $\mathbf{x}$ & $\mathbf{x}$ & $\mathbf{x}$ & $\mathbf{x}$ & $\mathbf{x}$ & $\mathbf{x}$ \\
\hline $\begin{array}{l}\text { action against tax } \\
\text { evasion, false/late } \\
\text { filings }\end{array}$ & & $\mathbf{x}$ & & $\mathbf{x}$ & & & $\mathbf{x}$ \\
\hline $\begin{array}{l}\text { better relationship } \\
\text { between tax body and } \\
\text { businesses, taxpayers }\end{array}$ & & & & $\mathbf{x}$ & $\mathbf{x}$ & & \\
\hline $\begin{array}{l}\text { strict monitoring of } \\
\text { EFDs and EFD-using } \\
\text { businesses }\end{array}$ & & & & $\mathbf{x}$ & & & \\
\hline $\begin{array}{l}\text { subsidised, or free, } \\
\text { EFDs }\end{array}$ & $\mathbf{x}$ & $\mathbf{x}$ & & & $\mathbf{x}$ & $\mathbf{x}$ & \\
\hline maintenance centres & & & & & $\mathbf{x}$ & & \\
\hline $\begin{array}{l}\text { fair estimates of } \\
\text { businesses'VAT } \\
\text { collections }\end{array}$ & & & & & & & $\mathbf{x}$ \\
\hline $\begin{array}{l}\text { involvement of } \\
\text { businesses in } \\
\text { programme design/ } \\
\text { implementation }\end{array}$ & & & & & & $\mathbf{x}$ & \\
\hline $\begin{array}{l}\text { provision of motivation } \\
\text { (incentives) to } \\
\text { businesses to use EFDs }\end{array}$ & & & & & & $\mathbf{x}$ & \\
\hline $\begin{array}{l}\text { appropriate legislation } \\
\text { and regulation }\end{array}$ & & & & & & $\mathbf{x}$ & \\
\hline $\begin{array}{l}\text { efforts to address } \\
\text { usability problems }\end{array}$ & & & $\mathbf{x}$ & & & & \\
\hline after-hours VAT filings & & & $\mathbf{x}$ & & & & \\
\hline
\end{tabular}




\begin{tabular}{|l|c|l|l|l|l|l|l|}
\hline $\begin{array}{l}\text { affordable and stable } \\
\text { power supply }\end{array}$ & & & $\mathbf{x}$ & & & & \\
\hline $\begin{array}{l}\text { EFDs compatible with } \\
\text { legacy systems }\end{array}$ & $\mathbf{x}$ & & & & & & \\
\hline robust EFDs & $\mathbf{x}$ & & & & & & \\
\hline $\begin{array}{l}\text { different EFDs for } \\
\text { different businesses }\end{array}$ & $\mathbf{x}$ & & & & & & \\
\hline
\end{tabular}

Figure 4 provides a percentage breakdown of the frequencies of the above-listed recommendations across the studies.

Figure 4: Recommendations: Frequency of citation, in \% terms, across the seven studies

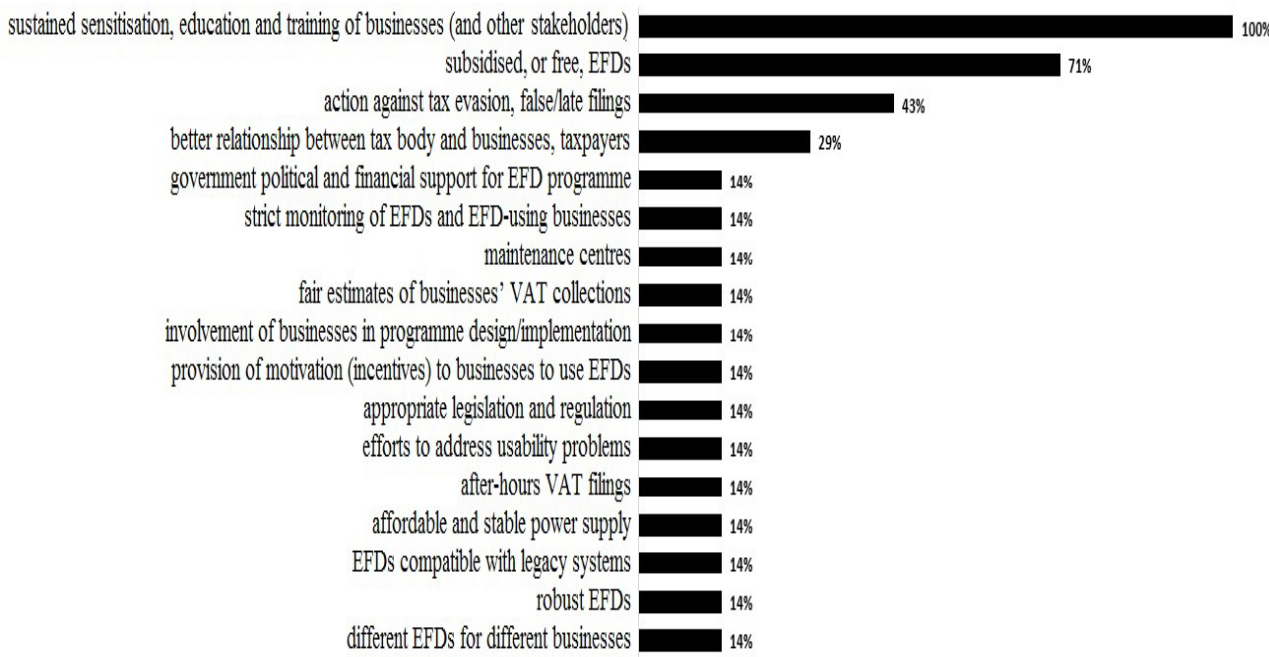

Results, as indicated in Figure 4, show that the most frequent recommendation, as suggested by all seven studies (100\%), was provision of sustained sensitisation, education and training of VAT-collecting businesses (and, to a lesser extent, other stakeholders) on the EFD system. The second-most-frequent recommendation, as suggested by four out of seven (71\%) of the studies, was to reduce the cost of EFDs through subsidisation or providing them free-of-charge. The third-most-frequent recommendation was for tax bodies to take stronger action against tax evasion, false filings, and late filings, as suggested by three out of seven (43\%) studies. The fourth-most-frequent recommendation, as suggested by two out seven (29\%) studies, was creating a good relationship between the tax body and VAT-collecting businesses and taxpayers. 
Recommendations that only appeared once across the seven studies were to: establish EFD maintenance centres; ensure fair VAT collection estimates for businesses; involve VAT-collecting businesses in EFD programme design and implementation; provide incentives to motivate businesses to use EFDs; ensure appropriate legislation and regulation; address usability problems; extend tax authority hours to enable tax filings after business hours; support affordable and stable electricity supply to power VATcollecting businesses' EFDs and EFD-related systems; make EFDs compatible with legacy systems; introduce more robust EFDs; introduce different EFDs for different types of businesses; ensure strict monitoring of EFDs and EFD-using businesses; and ensure government political and financial support for the EFD programme.

I now consider the 17 above-listed recommendations extracted from the seven studies, grouped according to the three TOE contexts as set out by Tornatzky and Fleischer (1990):

- technology $(\mathrm{T})$;

- organisation $(\mathrm{O})$; and

- environment (E).

\section{Technology $(T)$}

Usability: According to Maisiba and Atambo (2016), manufacturers of EFDs need to design easy-to-use EFDs, and tax bodies should come up with an application that can make tax registration, filing, and payment easy for the taxpayers.

Compatibility with legacy systems: Many traders complained that the new EFDs did not conform to their existing systems. There is a need for flexible EFDs that are compatible with legacy systems (Omweri et al., 2011)

More robust EFDs: One of the challenges of using EFDs, as pointed out by some VAT-collecting businesses, was that the devices were prone to malfunctions and errors. Omweri et al. (2011) recommend thorough testing of procured EFDs to ensure quality and robustness.

Different EFDs for different types of businesses: Some EFDs may not be appropriate for some businesses, creating a need to introduce different EFD systems for different types of businesses (Omweri et al., 2011).

\section{Organisation (O)}

Sustained sensitisation, education and training: Bakar (2014) observes that, for any EFD project to succeed, emphasis should be put on sensitisation, education and training programmes. This helps to inform all stakeholders on how to use EFDs and their benefits to the VAT-collecting business, the taxpayer, and to the government.

Subsidised or free EFDs: There is need to either subsidise the cost of EFDs or make them free. As seen from the challenges affecting the use of EFDs, the high cost of acquiring EFDs was second in importance to lack of training. Mativo et al. (2015) 
find that the financial implications of acquisition and maintenance of EFDs is a major hindrance to VAT compliance in Kenya.

Enforcement of the VAT law: Government is advised to be strict in enforcing VAT laws on VAT-collecting businesses. Mativo et al. (2015) find that that the government needs to strongly use the law in order to enforce the use of ETRs machines on every transaction.

Relations between the tax body and VAT-collecting businesses, taxpayers: There is a need for tax bodies to forge a strong relationship with VAT-collecting businesses. Siraji (2015) argues that the tax body should set up a public relations department to regularly visit VAT-collecting entities, talk to them, and get comments or suggestions on different aspects of EFD implementation.

Monitoring EFDs and the businesses using them: Bakar (2014) recommends effective monitoring of areas prone to faults in the system so as to address matters such as substandard EFDs, falsified breakages of EFDs, and collusion between revenue authority officers and traders in tax evasion (e.g., businesses collecting VAT but not paying it over to the authority).

EFD maintenance centres: Siraji (2015) recommends that tax bodies should set up maintenance centres where VAT-collecting businesses with EFDs would go to get the devices maintained and repaired.

Fairness in VAT collection estimations: Kapera (2017) observes that the tax body should have the ability to more accurately estimate VAT-collecting businesses' VAT collection totals. Over-estimating a particular business's collections and obligations will undermine the business.

Involvement of VAT-collecting businesses in EFD programme design and implementation: Involving VAT-collecting businesses in the whole design and implementation process for the EFD programme will enhance compliance (Kira, 2016).

Motivations for potential EFD-using businesses: According to Kira (2016), proving incentives to persuade businesses' adoption of EFDs is one way to influence acceptance. For example, giving out rewards to vendors who use EFDs will motivate other to adopt the devices.

Extension of tax authority hours: Based on VAT-collecting businesses' complaints that the time given to file VAT returns is too limited, Maisiba and Atambo (2016) recommend extension of tax authority working hours to suit the VAT-collecting entities' schedules.

\section{Environment (E)}

Government support: There is a need for the government to provide both political and financial support to the EFD implementation process (Bakar, 2017). 
Appropriate legislation and regulation: Fast-changing dynamics in technologydependent sectors often require legislative amendments or creation of new legislation. Kira (2016) calls for legislation with detailed regulations on use of technology in VAT collection, with the legislation developed with cognizance of the needs of both the VAT-collecting businesses and the tax authority.

Electricity supply to power EFDs: The government must ensure that all VAT-collecting businesses have access to affordable, stable electricity to run their EFDs and EFDrelated systems (Maisiba \& Atambo, 2016).

\section{Conclusion: A TOE-based model for EFD adoption in East Africa}

The concluding output made possible by this systematic review is a proposed model for EFD adoption in East Africa—generated by mapping the 17 recommendations (as just discussed, from the seven studies) in terms of the TOE framework. We saw in the previous sub-section that the 17 recommendations can be ordered against the three TOE contexts—technology $(\mathrm{T})$, organisation $(\mathrm{O})$, environment $(\mathrm{E})$ - as follows:

\section{Technology $(T)$}

In the technology context, we saw above that for EFDs and their related systems to be widely adopted, they must be: user-friendly; robust; compatible with legacy systems; and differentiated according to types of businesses.

\section{Organisation (O)}

In the organisation context, we saw above that wide adoption of EFDs and their related systems requires: sensitisation, education and training of businesses and other stakeholders; subsidised or free EFDs; enforcement of VAT law; good relations between the tax authority and businesses/taxpayers; monitoring of EFDs and their users; maintenance centres; fairness in VAT collection estimates; business involvement in EFD programme design and implementation; incentives for business EFD take-up; and provision for after-hours VAT filings.

\section{Environment (E)}

In the environment context, we saw that adoption of EFDs and EFD systems requires: government political and financial support; appropriate legislation and regulation; and affordable and stable electricity supply.

Accordingly, Figure 5 provides a graphical illustration of the TOE-based model just outlined for effective adoption of EFDs to leverage VAT compliance in East Africa. 
Figure 5: TOE-based model for EFD adoption in East Africa

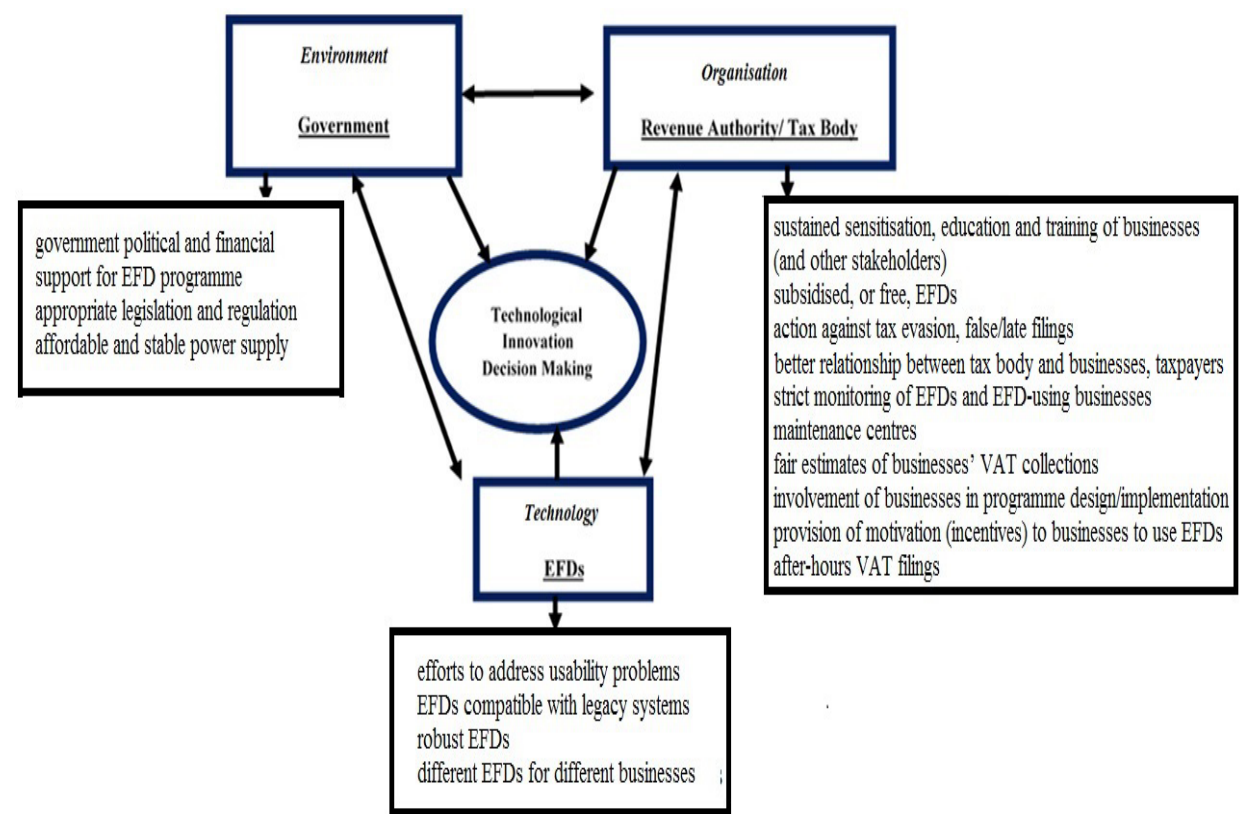

The TOE framework thus provides a suitable taxonomy for mapping the recommendations that emerge from the seven studies of EFD adoption in East Africa. It is hoped that this model may be of use to policymakers and ICT implementers seeking to deploy EFDs in support of VAT collection in East Africa, and potentially elsewhere on the African continent and the developing world.

\section{References}

African Development Bank (AfDB). (2011). Domestic resource mobilization for poverty reduction in East Africa: Lessons for tax policy and administration. Abidjan.

Ajzen, I. (1985). From intentions to actions: A theory of planned behavior. In P. D. J. Kuhl, \& D. J. Beckmann (Eds.), Action control (pp. 11-39). Berlin: Springer. Retrieved from http://link.springer.com/chapter/10.1007/978-3-642-69746-3 2

Ajzen,I. (1991). The theory of planned behavior. Organizational Behavior and Human Decision Processes, 50(2), 179-211. https://doi:10.1016/0749-5978(91)90020-T

Bakar, S. S. (2014). Impact of electronic fiscal devices on value added tax collection process: The case of Tanzania Revenue Authority-Tanga City. Master's dissertation, Master of Business Administration, Nzumbe University, Morogoro, Tanzania.

Carter, A., \& Cebreiro, A. (2011). Africa's tax system: A survey. OECD Observer, 284(Q1).

Casey, P., \& Castro, P. (2015). Electronic fiscal devices (EFDs): An empirical study of their impact on taxpayer compliance and administrative efficiency. IMF Working Paper. Washington DC: International Monetary Fund (IMF).

https://doi.org/10.5089/9781475521023.001 
Chege, A., Kiragu, N., Lagat, C., \& Muthoni, G. (2015). Effect of electronic fiscal devices on VAT collection in Tanzania: A case of Tanzania Revenue Authority. European Journal of Business and Management, 7(33), 125-133.

Davis, F. D. (1986). A technology acceptance model for empirically testing new end-user information systems: Theory and results. Sloan School of Management, Massachusetts Institute of Technology (MIT), Cambridge, MA.

Davis, F. D. (1989). Perceived usefulness, perceived ease of use, and user acceptance of information technology. MIS Quarterly, 13(3), 319-340. https://doi.org/10.2307/249008

Davis, F. D., Bagozzi, R.P., \&Warshaw, P. R. (1989).User acceptance of computer technology: A comparison of two theoretical models. Management Science, 35(8), 982-1003. https://doi.org/10.1287/mnsc.35.8.982

Department for International Development (DFID). (2013). Systematic reviews in international development. London.

Ebeke, C., \& Ehrhart, H. (2010). Tax revenue instability in Sub-Saharan Africa: Consequences and remedies. Retrieved from http://cerdi.org/uploads/ed/2010/2010.25.pdf

Eilu, E. (2018). Improving domestic revenue mobilisation in African countries using ICT: A literature review analysis. In S. Saeed, T. Ramayah, \& Z. Mahmood (Eds.), User centric e-government (pp. 47-61). Cham, Switzerland: Springer. https://doi.org/10.1007/978-3-319-59442-2_3

Fjeldstad, O. H. (2013). Taxation and development: A review of donor support to strengthen tax systems in developing countries. WIDER Working Paper No. 2013/010. Helsinki: United Nations University World Institute for Development Economics Research (UNU-WIDER). Retrieved from https://www.cmi.no/publications/file/4720taxation-and-development.pdf

Givens, G. H., Smith, D. D., \& Tweedie, R. L. (1997). Publication bias in meta-analysis: A Bayesian data-augmentation approach to account for issues exemplified in the passive smoking debate. Statistical Science, 12(4), 221-250.

https://doi.org/10.1214/ss/1030037958

Hagen-Zanker, J. H., \& Mallett, R. (2013) How to do a rigorous, evidence focused literature review in international development: A guidance note. London: Overseas Development Institute (ODI). Retrieved from https://www.odi.org/sites/odi.org.uk/files/ odiassets/publications-opinion-files/8572.pdf

Hoti, E. (2015). The technological, organizational and environmental framework of IS innovation adaption in small and medium enterprises. Evidence from research over the last 10 years. International Journal of Business and Management, 3(4), 1-14. https://doi.org/10.20472/bm.2015.3.4.001

Kapera, O.M. (2017). Assessment of effectiveness of electronic fiscal devices (EFDs) in tax collection in Tanzania: A case of Arusha City Council. Master's Dissertation, Master of Business Administration, Open University of Tanzania, Dar es Salaam.

Kira, R. A. (2016). The perceptions of taxpayers on the adoption of electronic fiscal devices (EFDs) in revenue collection in Tanzania: The case of Dodoma. International Journal of Academic Research in Business and Social Sciences, 6(12), 39-55. https://doi.org/10.6007/ijarbss/v6-i12/2468 
Lippert, S. K., \& Govindarajulu, C. (2006). Technological, organizational, and environmental antecedents to web services adoption. Communications of the IIMA, 6(1), 146-158.

Maisiba, G. J., \& Atambo, D. W. (2016). Effects of electronic-tax system on the revenue collection efficiency of Kenya Revenue Authority: A case of Uasin Gishu County. Imperial Journal of Interdisciplinary Research (IJIR), 2(4), 815-827.

Mascagni, G., Moore, M., \& McCluskey, R. (2014). Tax revenue mobilisation in developing countries: Issues and challenges. Brussels: Policy Department, Directorate-General for External Policies of the Union, European Parliament. Retrieved from https://www. ids.ac.uk/files/dmfile/TaxRevenueMobilisationinDevelopingCountries.pdf

Mativo, P. M., Muturi, W., \& Nyang'au, A. (2015). Factors affecting utilization of electronic tax registers (ETRs) in small and medium entrerpries [sic] in Kenya: A case of Nairobi CBD. International Journal of Economics, Commerce and Management, III(3), 1-25. Retrieved from http://ijecm.co.uk/wp-content/uploads/2015/03/3339.pdf

Naibei, K. I., \& Siringi, E. M., \& Musonera, E. (2012). Impact of electronic tax registers on VAT compliance: A study of private business firms. International Journal of Arts and Commerce, 6(1), 174-185. https://doi.org/10.4314/afrrev.v5i1.64511

Oliveira, T., \& Martins, M, F. (2011). Literature review of information technology adoption models at firm level. The Electronic Journal Information Systems Evaluation, 14(1), 110-121.

Omweri, M. L., Obongo, B. M., Obara, P. M., \& Onsongo, C. O. (2011). The effectiveness of electronic tax registers in processing of value added tax returns: Perspectives from registered VAT taxpayers in Kisii Town, Kenya. African Journal of Business $\mathcal{E}^{2}$ Management (AJBM), 1, 44-54.

Organisation for Economic Co-operation and Development (OECD). (2011). Revenue statistics, 1965-2010. Paris. https://doi.org/10.1787/19963726

Penduka, G. (2015). An assessment of the efficiency of fiscalised electronic devices in improving revenue collection in selected companies in Harare: The case of the fiscal electronic tax registers. Master's Dissertation, Master of Science in Public Administration, University of Zimbabwe, Harare.

Randolph,J.J.(2009). A guide to writing the dissertation literature review. Practical Assessment, Research Eo Evaluation, 14(13), 1-13. Retrieved from http://pareonline.net/pdf/ v14n13.pdf

Rogers, E. M. (1995). Diffusion of innovations (4th ed.). New York: Free Press.

Siraji, Y. K. (2015). Challenges faced by taxpayers in using electronic fiscal devices in Tanzania: A case study of selected taxpayers in Nyamagana District, Mwanza City. Master's dissertation, Master of Business Administration, Nzumbe University, Morogoro, Tanzania.

Slavin, R. E., \& Lake, C. (2008). Effective programs in elementary math: A best evidence synthesis. Review of Educational Research, 78(3), 427-515.

https://doi: $10.3102 / 0034654308317473$

Slavin, R. E., \& Madden, N.A. (2008). Understanding bias due to measures inherent to treatments in systematic reviews in education. Paper presented at the annual meetings of the Society for Research on Effective Education, Crystal City, VA, 3-4 March. 
Slavin, R. E., \& Smith, D. (2008). Effects of sample size on effect size in systematic reviews in education. Paper presented at the Annual Meetings of the Society for Research on Effective Education, Crystal City, VA, 3-4 March.

Slavin, R. E., Lake, C., \& Groff, C. (2009). Effective programs in middle and high school math: A best evidence synthesis. Review of Educational Research, 79(2), 839-911. https://doi:10.3102/0034654308330968

Steenbergen, V. (2017). Reaping the benefits of electronic billing machines: Using data-driven tools to improve VAT compliance. Working Paper. London: International Growth Centre (IGC), London School of Economics and Political Science (LSE). Retrieved from https://www.theigc.org/wp-content/uploads/2017/09/Steenbergen-working-paper. pdf

Sterne, J., Gavaghan, D., \& Egger, M. (2000). Publication and related bias in meta-analysis: Power of statistical tests and prevalence in the literature. Journal of Clinical Epidemiology, 53(11), 1119-1129.

Tornatzky, L., \& Fleischer, M. (1990). The process of technology innovation. Lexington, MA: Lexington Books.

Uganda Revenue Authority (URA). (2013). A comparative study of Uganda with selected East African countries and South Africa. Kampala. Retrieved from https://www.ura.go.ug/ Resources/webuploads/INLB/Tax\%20To\%20GDP\%20Report\%20-June\%2002. pdf

Valentine, J. C., Pigott, T. D., \& Rothstein, H. R. (2010). How many studies do you need? A primer on statistical power for meta-analysis. Journal of Educational and Behavioral Statistics, 35(2), 215-247. https://doi: 10.3102/1076998609346961

Venkatesh, V., Morris, M. G., Davis, G. B., \& Davis, F. D. (2003). User acceptance of information technology: Toward a unified view. MIS Quarterly, 27(3), 425-478. https://doi.org/10.2307/30036540

Venkatesh, V., Thong, J. Y., \& Xu, X. (2003). Consumer acceptance and use of information technology: Extending the unified theory of acceptance and use of technology. MIS Quarterly, 36(1), 157-178. https://doi.org/10.2307/41410412

World Bank. (2006). World development indicators 2006. Washington, DC. https://doi.org/10.1596/978-0-8213-6470-3

World Bank. (2010). World development indicators 2010. Washington, DC. https://doi.org/10.1596/978-0-8213-8232-5 